\title{
Impact of Distillery Spent Wash Irrigation on Sprouting, Growth and Yield of Dahlia (Asteraceae) Flowering Plant
}

\author{
S. CHANDRAJU ${ }^{* a}$, C. THEJOVATHI ${ }^{\mathrm{b}}$ and C. S. CHIDAN KUMAR ${ }^{\mathrm{b}}$ \\ ${ }^{\text {a } D e p a r t m e n t ~ o f ~ S t u d i e s ~ i n ~ S u g a r ~ T e c h n o l o g y, ~ S i r ~ M . ~ V i s h w e s w a r a y a ~ P o s t g r a d u a t e ~ C e n t e r, ~}$ \\ University of Mysore, Tubinakere, Mandya -571402, Karnataka, India \\ ${ }^{\mathrm{b}}$ Department of Chemistry, Alva's Institute of Engineering and Technology, Mijar, \\ Moodbidri-574225, South Canara Dt. Karnataka, India \\ chandraju@yahoo.com
}

Received 29 August 2012 / Accepted 19 September 2012

\begin{abstract}
Germination, growth and yield of Dahlia (Asteraceae) flowering plant was made by irrigated with distillery spent wash of different concentrations. Diluted spent wash (1:1, 1:2 and 1:3) were analyzed for plant nutrients such as nitrogen, phosphorous, potassium and other physical and chemical characteristics. Experimental soil was tested for its chemical and physical parameters. Dahlia seeds were sowed in different pots and irrigated with raw water (RW), 1:1, 1:2 and 1:3 spent wash (SW). The nature of germination, growth and yield of seeds was investigated. It was found that, the germination, growth and yield was very good $(100 \%)$ in $1: 3$ SW irrigation, while very poor (25\%) in $1: 1 \mathrm{SW}$, moderate $(80 \%)$ in $1: 2 \mathrm{SW}$ and $95 \%$ in RW irrigation. This concludes that the diluted spent wash can be conveniently used for irrigation purpose without adverse effect on soil.
\end{abstract}

Keywords: Distillery spent wash, Dahlia seeds, Irrigation

\section{Introduction}

Dahlia (Asteraceae) is a genus of bushy, tuberous, herbaceous perennial plants native to Mexico, Central America and Colombia. A member of the Asteraceae or Compositae, dicotyledonous plants related species include the sunflower, daisy, chrysanthemum and zinnia. If ever there was a flower that knew the meaning of variety, it is the Dahlia ${ }^{1}$. While its colors are limited to the warm ranges of red, orange, yellow, pink and white, its flowers come in a dizzying array of shapes and sizes. Each vacation of the Dahlia petals is a beauty. There petals can be spiky, wispy, round thin or a half dozen other variations. Even the color ranges from one solid color to a painted mixture of two or three colors. Dahlias are commonly grown as an annual but they can be grown as a perennial if tubers are dug up 
shortly after the first frost. There are at least 36 species of dahlia, with hybrids commonly grown as garden plants. Flower forms are variable, with one head per stem; these can be as small as in $(5.1 \mathrm{~cm})$ in diameter or up to $1 \mathrm{ft}(30 \mathrm{~cm})$ ("dinner plate"). This great variety results from dahlias being octoploids that is they have eight set of homologous chromosomes, whereas most plant have only two in addition, it is also contain many transposes genetic pieces that move from place to place upon an allele which contributes to their manifesting such great diversity ${ }^{2}$. The stems are leafy, ranging in height from as low as 12 in $30 \mathrm{~cm}$ to more than $6-8 \mathrm{ft}(1.8-2.4 \mathrm{~m})$. The majority of species do not produce scented flowers or cultivars. Like most plants that do not pollinating insects through scent, they are brightly colored displaying most hues, with the exception of blue. The dahlia was declared the national flower of Mexico in 1963. In Europe and America, prior to the discovery of insulin in 1923, diabetics as well as consumptives, were often given a substance called Atlantic starch or diabetic sugar, derived from inulin, a naturally occurring from of fruit sugar, extracted from dahlia tubers. Inulin is still used in clinical tests for kidney functionality.

Flowers are widely used throughout the globe for various purposes such as perfumes, beauty and hygiene products, food and drink, medicines and also used as repelling wildlife and hence floriculture is become commercially popular.

Ethanol is produced by the fermentation of molasses in distilleries. Now a day's demand of ethanol's increasing due to its usage as fuel blended with petrol and diesel. As a result more numbers of distilleries are coming out. About 08 (eight) liters of wastewater is generated for every liter of ethanol production in distilleries, known as raw spent wash (RSW), which is known for high biological oxygen demand (BOD: 5000-8000 mg/L) and chemical oxygen demand (COD: 25000-30000 mg/L), undesirable color and foul odor ${ }^{3}$. Discharge of RSW into open field or nearby water bodies' results in environmental, water and soil pollution including threat to plant and animal lives. The RSW is highly acidic and contains easily oxidisable organic matter with very high BOD and $\mathrm{COD}^{4}$. Also, spent wash contains high organic nitrogen and nutrients ${ }^{5}$. By installing biomethenation plant in distilleries, reduces the oxygen demand of RSW, the resulting spent wash is called primary treated spent wash (PTSW) and primary treatment to RSW increases the nitrogen (N), potassium $(\mathrm{K})$ and phosphorous $(\mathrm{P})$ contents and decreases calcium $(\mathrm{Ca})$, magnesium $(\mathrm{Mg})$, sodium (Na), chloride $\left(\mathrm{Cl}^{-}\right)$and sulphate $\left(\mathrm{SO}_{4}^{2-}\right)^{6}$. PTSW is rich in potassium $(\mathrm{K})$, sulphur $(\mathrm{S})$, nitrogen $(\mathrm{N})$, phosphorous $(\mathrm{P})$ as well as easily biodegradable organic matter and its application to soil has been reported to increase yield of sugar cane rice ${ }^{7}$, wheat and rice. Quality of groundnut ${ }^{8}$ and physiological response of soybean ${ }^{9}$. Diluted spent wash could be used for irrigation purpose without adversely affecting soil fertility ${ }^{10}$, seed germination and crop productivity ${ }^{11}$. The diluted spent wash irrigation improved the physical and chemical properties $^{12}$ of the soil ${ }^{13}$ and further increased soil micro flora ${ }^{14}$. Twelve pre-sowing irrigations with the diluted spent wash had no adverse effect on the germination of maize but improved the growth ${ }^{15}$ and yield. Diluted spent wash increases the growth of shoot length, leaf number per plant, leaf area and chlorophyll content of peas ${ }^{16}$. Increased concentration $^{17}$ of spent wash causes decreased seed germination, seedling growth and chlorophyll content in Sunflowers (Helianthus annuus) and the spent wash could safely used for irrigation purpose at lower concentration. The spent wash contained an excess of various forms of cations and anions, which are injurious to plant growth and these constituents should be reduced to beneficial level by diluting spent wash, which can be used as a substitute for chemical fertilizer ${ }^{18}$. The spent wash could be used as a complement to mineral 
fertilizer to sugarcane ${ }^{19}$. The spent wash contained $\mathrm{N}, \mathrm{P}, \mathrm{K}, \mathrm{Ca}, \mathrm{Mg}$ and S and thus valued as a fertilizer when applied to soil through irrigation with water ${ }^{20}$. The application of diluted spent wash increased the uptake of $\mathrm{Zinc}(\mathrm{Zn})$, Copper(Cu), Iron(Fe) and Manganese $(\mathrm{Mn})$ in maize and wheat as compared to control and the highest total uptake of these were found at lower dilution levels than at higher dilution levels. Mineralization of organic material as well as nutrients present in the spent wash was responsible for increased availability of plant nutrients. Diluted spent wash increase the uptake of nutrients, height, growth and yield of leaves vegetables ${ }^{21}$ nutrients of cabbage and mint leaf ${ }^{22}$, nutrients of top vegetables ${ }^{23}$, pulses, condiments, root vegetables, of some root vegetables in untreated and spent wash treated soil, yields of top vegetables (creepers) yields of tuber/root medicinal plants yields of leafy medicinal plants. And also increases the germination growth and yields of flowering plants.

However, no information is available on the studies of distillery spent wash irrigation on the germination, growth and yield of Dahlia flowering plant. Therefore, the present investigation was carried out to study the influence of different concentration of spent wash on the germination, growth and yield of Dahlia seeds.

\section{Experimental}

Physicochemical parameters ${ }^{24}$ and amount of nitrogen $(\mathrm{N})^{25}$, potassium $(\mathrm{K})^{26}$, phosphorous $(\mathrm{P})^{27}$ and sulphur $(\mathrm{S})^{28}$ present in the primary treated diluted spent wash $(1: 1,1: 2$ and $1: 3 \mathrm{SW})$ were analyzed by standard methods ${ }^{29}$. The PTSW was used for irrigation with a dilution of 1:1, 1:2 and1:3. A composite soil sample collected prior to spent wash irrigation was air-dried, powdered and analyzed for physicochemical properties $^{30}$. Flowering ${ }^{31}$ plants $^{32}$ selected for the present investigation were Dahlia. The seeds were sowed in different pots $50 \mathrm{~cm}(\mathrm{~h}), 30 \mathrm{~cm}$ (dia) and irrigated with raw water (RW), 1:1 SW, 1:2 SW and 1:3 SW at the dosage of twice a week and rest of the period with raw water as required (by applying $5-10 \mathrm{~mm} / \mathrm{cm}^{2}$ depends upon the climatic condition $)^{33}$. Cultivation was conducted in triplicate; in each case germination, growth and yield were recorded.

\section{Results and Discussion}

Chemical composition of PTSW, 1:1, 1:2 and 1:3 SW such as $\mathrm{pH}$, electrical conductivity, total solids (TS), total dissolved solids (TDS), total suspended solids (TSS), settelable solids (SS), chemical oxygen demand (COD), biological oxygen demand (BOD), carbonates, bicarbonates, total phosphorous (P), total potassium (K), ammonical nitrogen $(\mathrm{N})$, calcium $(\mathrm{Ca})$, magnesium $(\mathrm{Mg})$, sulphur $(\mathrm{S})$, sodium $(\mathrm{Na})$, chlorides (Cl), iron (Fe), manganese (Mn), zinc $(\mathrm{Zn})$, copper $(\mathrm{Cu})$, cadmium $(\mathrm{Cd})$, lead $(\mathrm{Pb})$, chromium (Cr) and nickel (Ni) were analyzed Table 1 . Amount of N, P, K and S contents are presented in Table 2. Characteristics of experimental soils such as $\mathrm{pH}$, electrical conductivity, the amount of organic carbon, available nitrogen $(\mathrm{N})$, phosphorous (P), potassium (K), sulphur (S), exchangeable calcium (Ca), magnesium $(\mathrm{Mg})$, sodium $(\mathrm{Na})$, DTPA iron $(\mathrm{Fe})$, manganese $(\mathrm{Mn})$, copper $(\mathrm{Cu})$ and zinc $(\mathrm{Zn})$ were analyzed and tabulated Table 3. It was found that the soil composition is fit for the cultivation of plants, because it fulfils all the requirements for the growth and yields of plants. It was found that the germination, growth and yield of plant was very good $(100 \%)$ in 1:3 SW irrigation, while very poor (25\%) in 1:1 SW, moderate (80\%) in 1:2 SW and $95 \%$ in RW irrigation growth. 
Table 1. Chemical characteristics of distillery spent wash

\begin{tabular}{|c|c|c|c|c|}
\hline Chemical parameters & PTSW & 1:1 PTSW & 1:2 PTSW & 1:3 PTSW \\
\hline $\mathrm{pH}$ & 7.57 & 7.63 & 7.65 & 7.66 \\
\hline Electrical conductivity ${ }^{\mathrm{a}}$ & 26400 & 17260 & 7620 & 5330 \\
\hline Total solids ${ }^{\mathrm{b}}$ & 47200 & 27230 & 21930 & 15625 \\
\hline Total dissolved solids ${ }^{\mathrm{b}}$ & 37100 & 18000 & 12080 & 64520 \\
\hline Total suspended solids ${ }^{\mathrm{b}}$ & 10240 & 5380 & 4080 & 1250 \\
\hline Settleable solids ${ }^{\mathrm{b}}$ & 9880 & 4150 & 2820 & 3240 \\
\hline $\mathrm{COD}^{\mathrm{b}}$ & 41250 & 19036 & 10948 & 2140 \\
\hline $\mathrm{BOD}^{\mathrm{b}}$ & 16100 & 7718 & 4700 & 2430 \\
\hline Carbonate $^{\mathrm{b}}$ & Nil & Nil & Nil & Nil \\
\hline Bicarbonate $^{\mathrm{b}}$ & 12200 & 6500 & 3300 & 1250 \\
\hline Total Phosphorous ${ }^{\mathrm{b}}$ & 40.5 & 22.44 & 17.03 & 10.80 \\
\hline Total Potassium ${ }^{\mathrm{b}}$ & 7500 & 4000 & 2700 & 1620 \\
\hline Calcium $^{\mathrm{b}}$ & 900 & 590 & 370 & 190 \\
\hline Magnesium $^{\mathrm{b}}$ & 1244.16 & 476.16 & 134.22 & 85 \\
\hline Sulphur ${ }^{b}$ & 70 & 30.2 & 17.8 & 8.4 \\
\hline Sodium ${ }^{b}$ & 520 & 300 & 280 & 140 \\
\hline Chlorides $^{\mathrm{b}}$ & 6204 & 3512 & 3404 & 2960 \\
\hline Iron $^{\mathrm{b}}$ & 7.5 & 4.7 & 3.5 & 2.1 \\
\hline Manganese $^{\mathrm{b}}$ & 980 & 495 & 288 & 160 \\
\hline Zinc $^{\mathrm{b}}$ & 1.5 & 0.94 & 0.63 & 0.56 \\
\hline Copper $^{b}$ & 0.25 & 0.108 & 0.048 & 0.026 \\
\hline Cadmium $^{\text {b }}$ & 0.005 & 0.003 & 0.002 & 0.001 \\
\hline Lead $^{\text {b }}$ & 0.16 & 0.09 & 0.06 & 0.003 \\
\hline Chromium $^{\text {b }}$ & 0.05 & 0.026 & 0.012 & 0.008 \\
\hline Nickel $^{\mathrm{b}}$ & 0.09 & 0.045 & 0.025 & 0.012 \\
\hline Ammonical Nitrogen ${ }^{\mathrm{b}}$ & 750.8 & 352.36 & 283.76 & 178 \\
\hline Carbohydrates $^{c}$ & 22.80 & 11.56 & 8.12 & 6.20 \\
\hline
\end{tabular}

Units: $a-\mu S, b-m g / L, c-\%, P T S W$ - Primary treated distillery spent wash

Table 2. Amount of N, P, K and S (Nutrients) in distillery spent wash

\begin{tabular}{lcccc}
\hline Chemical parameters & PTSW & 1:1 PTSW & 1:2 PT SW & 1:3 PTSW \\
\hline Ammonical Nitrogen $^{\mathrm{b}}$ & 750.8 & 352.36 & 283.76 & 160.5 \\
Total Phosphorous $^{\mathrm{b}}$ & 40.5 & 22.44 & 17.03 & 11.2 \\
Total Potassium $^{\mathrm{b}}$ & 7500 & 4000 & 2700 & 1800 \\
Sulphur $^{\mathrm{b}}$ & 70 & 30.2 & 17.8 & 8.6 \\
\hline
\end{tabular}

Unit: $b-m g / L, P T S W$ - Primary treated distillery spent wash 
Table 3. Characteristics of experimental soil

\begin{tabular}{lc}
\hline \multicolumn{1}{c}{ Parameters } & Values \\
\hline Coarse sand $^{\mathrm{c}}$ & 9.24 \\
Fine sand $^{\mathrm{c}}$ & 40.14 \\
Slit $^{\mathrm{c}}$ & 25.64 \\
Clay $^{\mathrm{c}}$ & 20.60 \\
$\mathrm{pH}(1: 2$ soln) & 8.12 \\
Electrical conductivity $^{\mathrm{a}}$ & 530 \\
Organic Carbon $^{\mathrm{c}}$ & 1.64 \\
Available Nitrogen $^{\mathrm{b}}$ & 412 \\
Available Phosphorous $^{\mathrm{b}}$ & 210 \\
Available Potassium $^{\mathrm{b}}$ & 110 \\
Exchangeable Calcium $^{\mathrm{b}}$ & 180 \\
Exchangeable Magnesium $^{\mathrm{b}}$ & 272 \\
Exchangeable Sodium $^{\mathrm{b}}$ & 113 \\
Available Sulphur $^{\mathrm{b}}$ & 330 \\
DTPA Iron $^{\mathrm{b}}$ & 204 \\
DTPA Manganese $^{\mathrm{b}}$ & 206 \\
DTPA Copper $^{\mathrm{b}}$ & 10 \\
DTPA Zinc $^{\mathrm{b}}$ & 55 \\
\hline
\end{tabular}

Units: $a-\mu S, b-m g / L, c-\%$

\section{Dahlia plants in different irrigations}

1:3 SW Germination, growth and yields of Dahlia (Asteraceae) flowering plants were very good in both 1:2 and 1:3 spent wash as compared to 1:1 SW and raw water. Table 5, this could be due to more absorption of plant nutrients (NPK) present in spent wash by plants at higher dilutions. It was also found that no negative impact of heavy metals like lead, cadmium and nickel on the leaves of Dahlia plants. The soil was tested after the harvest; found that there was no adverse effect on soil characteristics Table 4. In 1:1 SW germination, growth and yields was very poor, the plants dies after some days. This may be due to the high concentration of SW. It is found that the germination, growth and yields of both plants were largely influenced in case of 1:2 and 1:3 SW irrigations than with 1:1 SW and raw water. But 1:3 SW irrigation shows more uptakes of nutrients when compared to 1:2 SW in both plants Table 6. This could be due to the maximum absorption of nutrients by plants at more diluted spent wash. After harvest, soil has tested; found that there was no adverse effect on characteristics. Hence the spent wash can be conveniently used for irrigation purpose with required dilution without affecting environment soil.

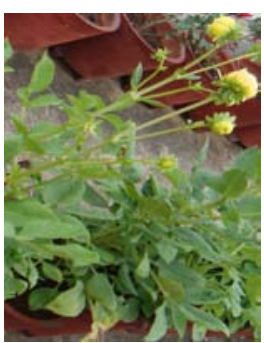

RW

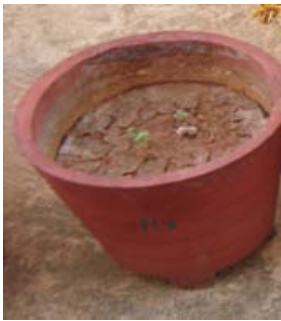

$1: 1 \mathrm{SW}$

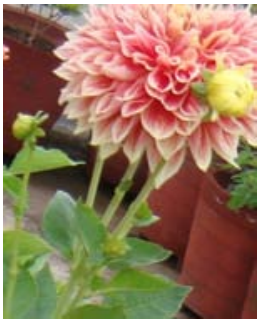

$1: 2 \mathrm{SW}$

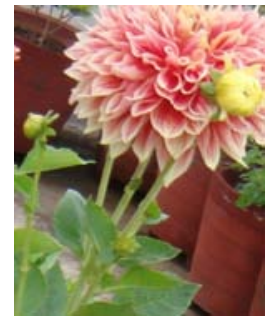

$1: 3 \mathrm{SW}$

Figure 1. Dahlia plants in different irrigations (RW-Raw water, SW-Spent wash) 
Table 4. Characteristics of experimental soil (After harvest)

\begin{tabular}{lc}
\hline \multicolumn{1}{c}{ Parameters } & Values \\
\hline Coarse sand $^{\mathrm{c}}$ & 9.69 \\
Fine sand $^{\mathrm{c}}$ & 41.13 \\
Slit $^{\mathrm{c}}$ & 25.95 \\
Clay $^{\mathrm{c}}$ & 24.26 \\
$\mathrm{pH}(1: 2$ soln $)$ & 8.27 \\
Electrical conductivity $^{\mathrm{a}}$ & 544 \\
Organic Carbon $^{\mathrm{c}}$ & 1.98 \\
Available Nitrogen $^{\mathrm{b}}$ & 434 \\
Available Phosphorous $^{\mathrm{b}}$ & 218 \\
Available Potassium $^{\mathrm{b}}$ & 125 \\
Exchangeable Calcium $^{\mathrm{b}}$ & 185 \\
Exchangeable Magnesium $^{\mathrm{b}}$ & 276 \\
Exchangeable Sodium $^{\mathrm{b}}$ & 115 \\
Available Sulphur $^{\mathrm{b}}$ & 337 \\
DTPA Iron $^{\mathrm{b}}$ & 212 \\
DTPA Manganese $^{\mathrm{b}}$ & 210 \\
DTPA Copper $^{\mathrm{b}}$ & 12 \\
DTPA Zinc $^{\mathrm{b}}$ & 60
\end{tabular}

Units: $a-\mu S, b-m g / L$

Table 5. Growth of Dahlia at different irrigations (cm)

\begin{tabular}{|c|c|c|c|}
\hline 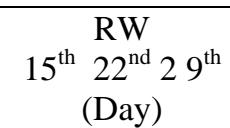 & $\begin{array}{c}1: 1 \mathrm{SW} \\
15^{\text {th }} 22^{\text {nd }} 29^{\text {th }} \\
(\text { Day })\end{array}$ & $\begin{array}{l}1: 2 \text { SW } \\
15^{\text {th }} 22^{\text {nd }} 29^{\text {th }} \\
\text { (Day) }\end{array}$ & $\begin{array}{c}1: 3 \text { SW } \\
15^{\text {th }} 22^{\text {nd }} 29^{\text {th }} \\
\text { (Day) }\end{array}$ \\
\hline $05, \quad 15, \quad 20$ & $03, \quad 03$ & $07, \quad 12, \quad 19$ & $09, \quad 18, \quad 29$ \\
\hline
\end{tabular}

Table 6. Yields of Dahlia Flowers at different irrigations. (Average number is taken from the five plants)

\begin{tabular}{cccccccc}
\hline \multicolumn{2}{c}{ RW } & \multicolumn{2}{c}{$1: 1 \mathrm{SW}$} & \multicolumn{2}{c}{$1: 2 \mathrm{SW}$} & \multicolumn{2}{c}{$1: 3 \mathrm{SW}$} \\
\hline $\begin{array}{c}\text { No. of } \\
\text { Flowers }\end{array}$ & $\begin{array}{c}\text { Size of } \\
\text { Flowers } \\
\mathrm{cm}\end{array}$ & $\begin{array}{c}\text { No. of } \\
\text { Flowers }\end{array}$ & $\begin{array}{c}\text { Size of } \\
\text { Flower } \\
\mathrm{cm}\end{array}$ & $\begin{array}{c}\text { No. of } \\
\text { Flowers }\end{array}$ & $\begin{array}{c}\text { Size of } \\
\text { Flowers } \\
\mathrm{cm}\end{array}$ & $\begin{array}{c}\text { No. of } \\
\text { Flowers }\end{array}$ & $\begin{array}{c}\text { Size of } \\
\text { Flowers } \\
\mathrm{cm}\end{array}$ \\
\hline 4 & 25 & -- & -- & 6 & 27 & 8 & 28 \\
\hline
\end{tabular}

\section{Conclusion}

It was found that the nutrients uptake in the sprouting, growth and yield of Dahlia plants were largely influenced in case of both 1:1, 1:2 and 1:3 SW irrigation than with raw water. In 1:1 spent wash irrigation seeds are not germinated (100\%), this could be due to the formation of thick layer of spent wash on the surface of the soil, which makes the mask on the seeds and hence 1:1 irrigation was not germinated. But 1:3 distillery spent wash shows more uptakes of $\mathrm{N}, \mathrm{P}$ and $\mathrm{K}$ when compared to 1:2 SW. After harvest, soil shows no adverse effect on its characteristics. Hence the spent wash can be conveniently used for irrigation with required dilution without affecting environment and soil.

\section{Acknowledgement}

Authors are grateful to The General Manager, Nijaveedu Sugars Limited. Koppa, Maddur Tq., Karnataka, for providing spent wash. 


\section{References}

1. Sunset Western Garden Book, 1995, 606.

2. Nation's Restaurant News Hibiscus blossoms as a food drink ingredient, Sunset Western Garden Book, 1995, 606-607.

3. Joshi H C, Kalra N, Chaudhary A and Deb D L, Asia Pac J Environ Develop., 1994, 1(2), 92-103.

4. Patil J D, Arabatti S V and Hapse D G, A review of some aspects of distillery spentwash (vinase) utilization in sugar cane, Bartiya sugar May, 1987, 9-15.

5. Ramadurai R and Gerard E J, SISSTA, Sugar J., 1994, 20, 129-131.

6. Mohamed Haroon A R and Subash Chandra Bose M, Use of distillery spentwash for alkali soil reclamation, treated distillery effluent for fertile irrigation of Crops, Indian Farm, March, 2004, 48.

7. Pathak H, Joshi H C, Chaudhary A, Chaudhary R, Kalra N and Dwivedi M K, $J$ Indian Soc Soil Sci., 1998, 46, 155-157.

8. $\quad$ Amar B S, Ashisk B and Sivakoti R, J Plant Nutri Soil Sci., 2003, 166, 345-347.

9. Ramana S, Biswas A K, Kundu S, Saha J K and Yadava R B R, Plant Soil Res., 2000, 2, 1-6.

10. Kaushik K, Nisha R, Jagjeeta K and Kaushik C P, Bio Resour Technol., 2005, 96(17), 1860.

11. Kuntal M H, Ashis K, Biswas A K and Misra K, Nutrition Soil Sci., 2004, 167(5), 584-590.

12. Raverkar K P, Ramana S, Singh A B, Biswas A K and Kundu S, Ann Plant Res., 2000, 2(2), 161-168.

13. Ramana S, Biswas A K, Kundu S, Saha J K and Yadava R B R, Bio-Resour Technol., 2001, 82(3), 273-275.

14. Devarajan L, Rajanna G, Ramanathan and Oblisami G, Performance of Field Crops Under Distillery Effluent Irrigations, Kisan World, 1994, 21, 48-50.

15. Singh Y and Raj Bahadur, Indian J Agri Sci., 1998, 68(2), 70-74.

16. Rani R and Sri Vastava M M, Int J Ecology Environ Sci., 1990, 16, 125-132.

17. Rajendran K, Indian Botanical Contactor, 1990, 7, 139-144.

18. Sahai R, Jabeen S and Saxena P K, Indian J Ecol., 1983, 10(1), 7-10.

19. Chares S, Vinasse in the fertilization of sugarcane. Sugarcane, 1985, 1, 20.

20. Samuel G, The use of alcohol distillery waste as a fertilizer, Proceedings of International American Sugarcane Seminar, 1986, 245-252.

21. Chandraju S and Basavaraju H C, Sugar J (SISSTA), 2007, 20.

22. Chandaraju S, Siddappa and Chidan Kumar C S, Bio-Res Bull., 2007, 5, 1-10.

23. Chandraju S, Siddappa and Chidan Kumar C S, Current Botany, 2011, 2(3), 38-42.

24 Manivasakam N, Physiochemical examination of water, sewage and Industrial effluent. Pragathi Prakashan, Merut., 1987.

25. Piper C S, Soil and Plant Analysis, Han’s Publication, Bombay, 1966.

26. Jackson M L, Soil Chemical Analysis. Prentice Hall of India Pvt. Ltd., New Delhi, 1973, 38-82.

27. Walkley A J and Black C A, Soil Sci., 1934, 37(1), 29-38.

28. Subbiah B V and Asija G L, Cur Sci., 1956, 25, 259.

29. Black C A, Methods of Soil Analysis. Part 2, Agronomy monograph No. 9. Am. Soc. Agron, Madison, Wisconsin, USA, pp.1965, 15.

30. Lindsay W L and Norve W A, Soil Sci Soc Am J., 1978, 42, 421-428.

31. Chandraju S, Thejovathi C and Chidan Kumar C S, Plant Biology, 2011, 1(2), 6-13.

32. Chandraju S, Thejovathi C and Chidan Kumar C S, SISSTA, 2011, 15.

33. Chandraju S, Thejovathi C and Chidan Kumar C S, J Chem Pharm Res., 2011, 3(5), 376. 